\title{
Effect of Plant Geometry, Fertility Level and Zinc Level on Kharif Baby Corn (Zea mays L.)
}

\author{
Alka Jyoti Sharma ${ }^{1 *}$, M.K. Singh ${ }^{1}$, Sanjay Kumar ${ }^{1}$ and Shweta Shambhavi \\ ${ }^{1}$ Department of Agronomy, Bihar Agricultural University Sabour, India \\ ${ }^{2}$ Department of Soil Science and Agricultural Chemistry, Bihar Agricultural University \\ Sabour, India
}

*Corresponding author

\section{A B S T R A C T}

A Field experiments were carried out on sandy loam soil at Sabour during kharif season of 2018 to evaluate appropriate plant geometry, fertility levels

Keywords

Plant geometry,

Fertility, Zinc,

Maize (Zea mays

L.)

Article Info

Accepted:

12 June 2019

Available Online:

10 July 2019 and zinc lvel for baby corn (Zea mays L.). Experiment was laid out in splitplot design and replicated thrice with three plant geometry viz. $\mathrm{P}_{1}(40 \mathrm{X} 20 \mathrm{~cm})$, $\mathrm{P}_{2}(50 \times 15 \mathrm{~cm})$ and $\mathrm{P}_{3}$ (paired row at $50+30 \times 20 \mathrm{~cm}$ ) in main plot, three levels of fertility (kg NPK/ha) viz. $F_{1}(120: 60: 60), F_{2}(150: 75: 75)$ and $F_{3}(180: 90: 90)$ in sub plot whereas, two levels of zinc (kg/ha) viz., $Z_{1}(2.5)$ and $Z_{2}(5.0)$ in sub-sub plot. Significant increase in baby corn yield $\left(14.34 \mathrm{q} \mathrm{ha}^{-1}\right)$, green fodder yield (267.822q ha ${ }^{-1}$ ) and net return (Rs $225774 \mathrm{ha}^{-1}$ ) and B: C ratio (5.12) in baby corn was recorded with paired row plant geometry. The baby corn yield (13.92q ha $\mathrm{q}^{-1}$ ), green fodder yield (278.91q ha $\mathrm{ha}^{-1}$ ) and net return (Rs $219108 \mathrm{ha}^{-1}$ ) and $\mathrm{B}$ : C ratio (4.81) was significantly higher with fertility level 180: 90: $90 \mathrm{~kg} \mathrm{~N} \mathrm{P}_{2} \mathrm{O}_{5} \mathrm{~K}_{2} \mathrm{O} /$ ha. Higher level of zinc had improved baby corn yield (13.38q ha $\left.{ }^{-1}\right)$, green fodder yield (277.7q ha' $\mathrm{ha}^{-1}$ ) and net return (Rs 211821 $\mathrm{ha}^{-1}$ ) and B: C ratio (4.77) with successive increase in zinc level up to maximum level of fertility $\mathrm{Zn}_{2}\left(5.0 \mathrm{~kg} \mathrm{ha}^{-1}\right)$.

\section{Introduction}

Maize (Zea mays L.) is grown on an area of $9.5 \mathrm{~m}$ ha, with production and productivity of $25.0 \mathrm{mt}$ and $26.3 \mathrm{q} \mathrm{ha}^{-1}$, respectively (Anon. 2017-18) in India. The crispy nature of baby corn and its high nutritional value (86-89\% moisture, $8.2 \mathrm{~g}$ carbohydrate, $2 \mathrm{~g}$ protein, 0.2 $\mathrm{g}$ fat, $0.28 \mathrm{mg}$ calcium, $0.86 \mathrm{mg}$ phosphorus,
$0.11 \mathrm{mg}$ iron, $0.05 \mathrm{mg}$ thiamin, $0.08 \mathrm{mg}$ riboflavin, $11 \mathrm{mg}$ ascorbic acid per $100 \mathrm{~g}$ of fresh baby corn) has made it of special choice among the elite group of people (Das et al., 2009). Its consumption is considered ecofriendly because it is free from the residue of pesticides by virtue of natural protection through many layers of husk. After harvesting of baby corn, quality palatable green fodder is 
used for cattle feed. At the same time it will also strengthen the cropping system (ricewheat) and explore the possibilities of generating more income and employment for farming community of the region especially in periurban areas. The diara area of Bihar is generally flooded after second week of August every year, which may be utilized for kharif baby corn where short duration baby corn may be harvest before flood occurrence. Baby corn has prime place as a safe and quality vegetable. Maize for baby corn may be grown as a best substitute for grain maize cultivation to get better economic returns because it is harvested in short time (within 65-75 days) which provides sweet, succulent and delicious green cobs and 3-4 crops of baby corn can be taken through staggered planting in a season and with good quality of palatable green fodder. The short duration of the crop enables it to escape from many abiotic stresses expected to occur in the later part of the season. It is emerging worldwide as one of the high value crops due to its high nutritive value, delicious taste, low calorie vegetable having higher fiber content without cholesterol and very large demand by the foreign tourists. Crop geometry vary widely in different parts of the world because great abundance of maize strains and their distribution all over the globe in different climatic conditions. Crop geometry is one of the important factors for higher production as it determines the optimum plant population of a crop. Baby corn is heavy feeder of nutrients, its productivity is largely dependent on nutrient management. Their application may assist in obtaining maximum production of baby corn, but the excessive use of chemical fertilizers has been associated with decline in soil physical and chemical properties and crop yield (Kumar et al., 2016). Zinc fertilization are used to increase micronutrient in edible parts to reduce the micro nutrient deficiency in human populations. For quality improvement of edible parts of crop, for enhancement of yield and zinc concentration in plants, $\mathrm{Zn}$ is extensively used.

\section{Materials and Methods}

A experiment was carried out at Research farm, Bihar Agricultural University, Sabour during kharif season of 2018. The farm is situated at $25^{\circ} 50^{\prime} \mathrm{N}$ latitude, $87^{\circ} 19^{\prime} \mathrm{E}$ longitude and at an altitude of $52.73 \mathrm{~m}$ above mean sea level. The sandy-loam soil of the experimental field was low in organic carbon $(0.50 \%)$ and available $\mathrm{N}(182.3 \mathrm{~kg} / \mathrm{ha})$, medium in available $\mathrm{P}(37.7 \mathrm{~kg} / \mathrm{ha})$ and $\mathrm{K}$ $(190.7 \mathrm{~kg} / \mathrm{ha})$ with $\mathrm{pH}$ 7.5. The experiment was laid out in split-plot design with three level of plant geometry viz. $\mathrm{P}_{1}(40 \mathrm{X} 20 \mathrm{~cm}), \mathrm{P}_{2}$ $\left(50 \times 15 \mathrm{~cm}\right.$ ) and $\mathrm{P}_{3}$ (paired row at $50+30 \times 20$ $\mathrm{cm})$ in main plot, three levels of fertility $(\mathrm{kg}$ NPK/ha) viz. $F_{1}(120: 60: 60), F_{2}$ (150:75:75) and $F_{3}(180: 90: 90)$ in sub plot whereas, two levels of zinc (kg/ha) viz., $\mathrm{Z}_{1}(2.5)$ and $\mathrm{Z}_{2}$ (5.0) in sub-sub plot and replicated thrice. Crop was sown on $2^{\text {nd }}$ June 2018 on levelled soil by opening $5 \mathrm{~cm}$ deep furrow at as per spacing of treatments. The different doses of fertilizers were applied as per the treatments. Full amount of phosphatic and potassic fertilizer, zinc and half amount of nitrogenous fertilizer were applied as uniformly as possible before sowing. The rest half of the nitrogenous fertilizer was applied as top dressing during the time of earthing up and detasseling stage. The field was kept free from weeds. Harvesting of baby corn was done at 2-3 days of silk emergence stage by leaving border rows. These baby cobs were counted weighted and thereafter husked and silk was removed and baby corn yield was recorded.

\section{Statistical analysis}

The data on various observations were statistically analyzed by the procedure of analysis of variance for split-plot design (SPD) given by Panse and Sukhatma (1985). 
For significant ' $F$ ' test, critical difference (CD) was reported at 5 per cent probability level.

\section{Results and Discussion}

Effect of Plant geometry, fertility and zinc on growth characters

The different spacing treatments has been found to exert a significant difference on crop growth in terms of plant height and leaf area index plant height except during initial stage of growth. The data regarding plant height at harvest revealed that high plant density $50 \mathrm{~cm}$ x $15 \mathrm{~cm}$ spacing had significantly higher plant height and LAI as compared to other spacing treatments. The higher plant height in closer spacing might be attributed to increase in competition for sunlight, nutrients, space and water by the plants which coupled with favourable climatic conditions especially temperature might have resulted in maximum plant height. The results are in conformity with the findings of Kunjir et al., (2007) who also recorded higher plant height with closer spacing as compared over wider spacing. Higher leaf area index in closer spacing was observed due to increased plant density which accommodates more number of plants and can also be ascribed to lesser value of spacing (Wasnik et al., 2012).

The crop sown under $\mathrm{P}_{3}$ (paired row at $50+30$ $\mathrm{x} 20 \mathrm{~cm}$ ) resulted significant values of no of leaves, dry matter accumulation. This might be due to the fact that lesser competition between the plants under paired row spacing which might have provided sufficient space to the crop for harnessing the solar energy and effective utilization of nutrients and moisture.

As regards to fertility level, $\mathrm{F}_{3}(180: 90: 90 \mathrm{~kg}$ $\mathrm{N}: \mathrm{P}_{2} \mathrm{O}_{5}: \mathrm{K}_{2} \mathrm{O}$ ha $^{-1}$ ) recorded significantly higher values of growth characters (plant height, no of leaves, LAI, dry matter accumulation and SPAD) but remained at par to preceding fertility level $F_{2}(150: 75: 75 \mathrm{~kg}$ $\mathrm{N}: \mathrm{P}_{2} \mathrm{O}_{5}: \mathrm{K}_{2} \mathrm{O} \mathrm{ha}^{-1}$ ) at almost all the growth stages. This might be due to the more availability of nutrients in soil. These results are in line with Khadtare et al., (2006) and Dadarwal et al., (2009). Irrespective of variation in the level of fertility, balance application of $\mathrm{N}, \mathrm{P}$ and $\mathrm{K}$ enables the crop to produce taller plants and more number of active leaves which ultimately caused more dry matter accumulation. The dry matter accumulation was initially slow because of slow growth during early stages (lag phase) primarily due to lower assimilating surface which rendered lower rate of photosynthesis and consequently less dry matter production during the initial stage of crop growth. Results obtained Sahoo and Mahapatra (2007), Singh and Choudhary (2008).

It is obvious from data that zinc supply caused significant effect on growth characters (plant height, no of leaves, LAI, dry matter accumulation).Tallest plant was noticed in $\mathrm{Zn}_{2}$ $\left(5.0 \mathrm{~kg} \mathrm{ha}^{-1}\right)$. As Zinc fertilization has beneficial effect on physiological process, plant metabolism and plant growth. Similar observation was noticed by Kumar and Bohra (2014) with application of zinc in maize. Application of $Z_{2}\left(5 \mathrm{~kg} \mathrm{Zn} \mathrm{ha}{ }^{-1}\right)$ exerted significant increase in LAI and dry matter accumulation over $\mathrm{Z}_{1}\left(2.5 \mathrm{~kg} \mathrm{ha}^{-1}\right)$ this happened due to zinc application which takes part in metabolism of plant as an activator of several enzymes and in turn may directly or indirectly affect the synthesis of carbohydrate and protein. These results are in conformity with the results Arya and Singh (2000). Nitrogen and zinc also helps in manufacturing more leaf area as a consequence more assimilates production. Similarly more vegetative development by nitrogen resulted in increased mutual shading and intermodal expansion was also reported by Asif et al., (2013) (Table 1). 
Table.1 Effect of plant geometry, fertility and zinc level on growth characters of baby corn at harvest

\begin{tabular}{|c|c|c|c|c|}
\hline Treatments & Plant height (cm) & No of leaves plant ${ }^{-1}$ & LAI & Dry weight (g plant ${ }^{1}$ ) \\
\hline \multicolumn{5}{|l|}{ Plant geometry } \\
\hline$P_{1}(40 \times 20 \mathrm{~cm})$ & 203.67 & 10.39 & 3.75 & 101.29 \\
\hline$P_{2}(50 X 15 \mathrm{~cm})$ & 212.07 & 9.98 & 4.26 & 97.84 \\
\hline $\mathbf{P}_{3}($ Paired row $)$ & 205.63 & 10.63 & 4.12 & 103.35 \\
\hline S Em \pm & 1.59 & 0.12 & 0.08 & 1.04 \\
\hline $\mathrm{CD}(\mathrm{P}=0.05)$ & 6.26 & 0.48 & 0.30 & 4.09 \\
\hline \multicolumn{5}{|c|}{ Fertility level $\left(\mathrm{N}: \mathrm{P}_{2} \mathrm{O}_{5}: \mathrm{K}_{2} \mathrm{O} \mathrm{kg} \mathrm{ha}^{-1}\right)$} \\
\hline$F_{1}(120: 60: 60)$ & 201.85 & 9.93 & 3.61 & 98.75 \\
\hline$F_{2}(150: 75: 75)$ & 208.09 & 10.46 & 4.01 & 100.64 \\
\hline$F_{3}(180: 90: 90)$ & 211.43 & 10.61 & 4.50 & 103.08 \\
\hline S Em \pm & 1.96 & 0.13 & 0.05 & 0.78 \\
\hline $\mathrm{CD}(\mathrm{P}=\mathbf{0 . 0 5})$ & 6.04 & 0.40 & 0.16 & 2.42 \\
\hline \multicolumn{5}{|l|}{ Zinc level $\left(\mathrm{Zn} \mathrm{kg} \mathrm{ha}^{-1}\right)$} \\
\hline $\mathrm{Z}_{1}(2.5)$ & 205.65 & 10.25 & 3.94 & 99.90 \\
\hline $\mathrm{Z}_{2}(5.0)$ & 208.59 & 10.42 & 4.14 & 101.75 \\
\hline $\mathbf{S E m} \pm$ & 1.59 & 0.10 & 0.02 & 0.40 \\
\hline $\mathrm{CD}(\mathrm{P}=\mathbf{0 . 0 5})$ & NS & NS & 0.06 & 1.19 \\
\hline \multicolumn{5}{|l|}{ Interaction } \\
\hline $\mathbf{P} \times \mathbf{F}$ & NS & NS & $\mathrm{S}$ & NS \\
\hline $\mathbf{F} \times \mathbf{Z}$ & NS & NS & NS & NS \\
\hline $\mathbf{P} \times \mathbf{Z}$ & NS & NS & NS & $\mathrm{S}$ \\
\hline $\mathbf{P} \times \mathbf{F} \times \mathrm{Z}$ & NS & NS & NS & NS \\
\hline
\end{tabular}


Table.1A Interaction effect of plant geometry and fertility level on leaf area index at harvest

\begin{tabular}{|c|c|c|c|c|}
\hline Treatment & $\mathbf{F}_{\mathbf{1}}$ & $\mathbf{F}_{\mathbf{2}}$ & $\mathbf{F}_{\mathbf{3}}$ & Mean \\
\hline $\mathbf{P}_{\mathbf{1}}$ & 3.60 & 3.69 & 3.97 & 4.75 \\
\hline $\mathbf{P}_{\mathbf{2}}$ & 3.69 & 4.24 & 4.84 & 4.12 \\
\hline $\mathbf{P}_{\mathbf{3}}$ & 3.54 & 4.11 & 4.71 & \\
\hline Mean & 3.61 & 4.01 & & \\
\hline SEm \pm & 0.09 & & \\
\hline
\end{tabular}

Table.1b Interaction effect of plant geometry and zinc level on dry matter accumulation (g/plant) at harvest

\begin{tabular}{|c|c|c|c|}
\hline Treatment & $\mathbf{Z}_{\mathbf{1}}$ & $\mathbf{Z}_{\mathbf{2}}$ & Mean \\
\hline $\mathbf{P}_{\mathbf{1}}$ & 100.52 & 102.06 & 101.29 \\
\hline $\mathbf{P}_{\mathbf{2}}$ & 96.85 & 98.82 & 103.35 \\
\hline $\mathbf{P}_{\mathbf{3}}$ & 102.32 & 104.37 & \\
\hline Mean & 99.90 & 101.75 & \\
\hline SEm \pm & 0.69 & & \\
\hline C.D. & 2.05 & & \\
\hline
\end{tabular}


Table.2 Effect of plant geometry, fertility and zinc level on yield attributes of baby corn

\begin{tabular}{|c|c|c|c|c|c|c|}
\hline Treatments & $\begin{array}{c}\text { Baby cob } \\
\text { length }(\mathrm{cm})\end{array}$ & $\begin{array}{l}\text { Baby corn } \\
\text { length }(\mathrm{cm})\end{array}$ & $\begin{array}{l}\text { Baby corn } \\
\text { girth }(\mathrm{cm})\end{array}$ & $\begin{array}{c}\text { Baby cob } \\
\text { weight (g) } \\
\text { plant }^{-1}\end{array}$ & $\begin{array}{l}\text { Baby corn } \\
\text { weight (g) plant }\end{array}$ & $\begin{array}{c}\text { Barren plant } \\
\left(\text { ha }^{-1}\right)\end{array}$ \\
\hline \multicolumn{7}{|l|}{ Plant geometry } \\
\hline$P_{2}(50 X 15 \mathrm{~cm})$ & 19.78 & 9.41 & 3.52 & 37.33 & 10.51 & 12988 \\
\hline $\mathbf{P}_{3}$ (Paired row) & 20.90 & 10.23 & 4.01 & 46.89 & 13.08 & 11357 \\
\hline $\mathrm{CD}(\mathrm{P}=\mathbf{0 . 0 5})$ & 0.97 & 0.57 & 0.18 & 4.66 & 1.41 & 342 \\
\hline \multicolumn{7}{|c|}{ Fertility level (N:P $\left.\mathrm{P}_{5}: \mathrm{K}_{2} \mathrm{O} \mathrm{kg} \mathrm{ha}^{-1}\right)$} \\
\hline$F_{1}(120: 60: 60)$ & 19.73 & 9.44 & 3.58 & 38.67 & 10.32 & 13122 \\
\hline$F_{2}(150: 75: 75)$ & 20.16 & 9.81 & 3.75 & 40.81 & 11.02 & 12846 \\
\hline$F_{3}(180: 90: 90)$ & 20.56 & 10.00 & 3.78 & 44.88 & 13.15 & 10020 \\
\hline $\mathrm{Z}_{1}(\mathbf{2 . 5})$ & 19.76 & 9.63 & 3.64 & 40.28 & 11.18 & 12193 \\
\hline $\mathrm{Z}_{2}(\mathbf{5 . 0})$ & 20.54 & 9.87 & 3.77 & 42.62 & 11.82 & 11798 \\
\hline S Em \pm & 0.12 & 0.08 & 0.03 & 0.44 & 0.13 & 62 \\
\hline $\mathrm{CD}(\mathrm{P}=\mathbf{0 . 0 5})$ & 0.34 & NS & 0.08 & 1.30 & 0.38 & 185 \\
\hline \multicolumn{7}{|l|}{ Interaction } \\
\hline $\mathbf{P} \times \mathbf{F}$ & NS & NS & NS & NS & NS & S \\
\hline $\mathbf{F} \times \mathbf{Z}$ & NS & NS & NS & NS & NS & $\mathrm{S}$ \\
\hline $\mathbf{P} \times \mathbf{Z}$ & NS & NS & NS & NS & NS & NS \\
\hline $\mathbf{P} \times \mathbf{F} \times \mathbf{Z}$ & NS & NS & NS & NS & NS & NS \\
\hline
\end{tabular}


Table.3 Effect of plant geometry, fertility and zinc level on yield and economics of baby corn

\begin{tabular}{|c|c|c|c|c|c|c|}
\hline Treatments & $\begin{array}{c}\text { Baby cob yield } \\
\left(\mathrm{q} \mathrm{ha}{ }^{-1}\right)\end{array}$ & $\begin{array}{c}\text { Baby corn yield } \\
\qquad\left(\mathrm{q} \mathrm{ha}{ }^{-1}\right)\end{array}$ & $\begin{array}{c}\text { Green } \\
\text { fodder yield } \\
\left(q \mathbf{h a}^{-1}\right)\end{array}$ & $\begin{array}{l}\text { Gross return } \\
{\left(\mathrm{Rs} \mathrm{ha}^{-1}\right.}^{-1}\end{array}$ & $\begin{array}{c}\text { Net return (Rs } \\
\left.\text { ha }^{-1}\right)\end{array}$ & B: C Ratio \\
\hline \multicolumn{7}{|l|}{ Plant geometry } \\
\hline$P_{1}(40 \times 20 \mathrm{~cm})$ & 50.77 & 13.06 & 265.20 & 248949 & 204868 & 4.64 \\
\hline$P_{2}(50 X 15 \mathrm{~cm})$ & 46.90 & 12.09 & 284.24 & 238223 & 193782 & 4.35 \\
\hline $\mathbf{P}_{3}$ (Paired row) & 54.91 & 14.34 & 267.82 & 269855 & 225774 & 5.12 \\
\hline S Em \pm & 0.84 & 0.21 & 3.58 & 2944 & 2944 & 0.07 \\
\hline $\mathrm{CD}(\mathrm{P}=0.05)$ & 3.30 & 0.83 & 14.05 & 11560 & 11560 & 0.26 \\
\hline \multicolumn{7}{|c|}{ Fertility level $\left(\mathrm{N}: \mathrm{P}_{2} \mathrm{O}_{5}: \mathrm{K}_{2} \mathrm{O} \mathrm{kg} \mathrm{ha}^{-1}\right)$} \\
\hline$F_{1}(120: 60: 60)$ & 46.87 & 12.05 & 266.10 & 235512 & 192642 & 4.49 \\
\hline$F_{2}(150: 75: 75)$ & 52.04 & 13.52 & 272.25 & 256875 & 212673 & 4.81 \\
\hline$F_{3}(180: 90: 90)$ & 53.66 & 13.92 & 278.91 & 264641 & 219108 & 4.81 \\
\hline $\mathbf{S E m} \pm$ & 0.59 & 0.12 & 1.34 & 2606 & 2606 & 0.06 \\
\hline $\mathrm{CD}(\mathrm{P}=0.05)$ & 1.81 & 0.37 & 4.14 & 8031 & 8031 & 0.18 \\
\hline \multicolumn{7}{|c|}{ Zinc level (Zn kg ha $\left.{ }^{-1}\right)$} \\
\hline $\mathrm{Z}_{1}(\mathbf{2 . 5})$ & 50.11 & 12.95 & 267.14 & 248473 & 204461 & 4.64 \\
\hline $\mathrm{Z}_{2}(5.0)$ & 51.61 & 13.38 & 277.70 & 256212 & 211821 & 4.77 \\
\hline $\mathbf{S} \operatorname{Em} \pm$ & 0.52 & 0.13 & 0.94 & 1999 & 1999 & 0.05 \\
\hline $\mathrm{CD}(\mathrm{P}=0.05)$ & NS & NS & 2.78 & 5939 & 5939 & NS \\
\hline \multicolumn{7}{|l|}{ Interaction } \\
\hline $\mathbf{P} \times \mathbf{F}$ & S & $\mathrm{S}$ & NS & $\mathrm{S}$ & $\mathrm{S}$ & NS \\
\hline $\mathbf{F} \times \mathbf{Z}$ & NS & NS & $\mathrm{S}$ & NS & NS & NS \\
\hline $\mathbf{P} \times \mathbf{Z}$ & NS & NS & NS & NS & NS & NS \\
\hline$P \times F \times Z$ & $\mathrm{~S}$ & NS & NS & $\mathrm{S}$ & $\mathrm{S}$ & NS \\
\hline
\end{tabular}


Effect of plant geometry, fertility and zinc on yield attributes and yield of baby corn

Yield attributes i.e, baby cob length, baby corn length, baby corn girth, baby corn weight (g) plant ${ }^{-1}$, baby cob weight (g) plant ${ }^{-1}$, total cob and baby corn yield $\mathrm{q} \mathrm{ha}^{-1}$, were significantly higher in $\mathrm{P}_{3}$ (paired row). The crop under the wider spacing has utilized the available resources more efficiently and hence, producing more number of cobs plant ${ }^{1,}$ higher cob weight attributing to higher cob yield plant ${ }^{-1}$. However, the crop under closer geometry $\mathrm{P}_{2}$ level $(50 \mathrm{~cm} \times 15 \mathrm{~cm})$ of plant geometry exhibited highest fodder yield as compared to the wider geometry though the values of yield attributes were poor with closer spacing. The fodder yield might have compensated these because of more number of plants $\mathrm{ha}^{-1}$. The result is similar to the findings of Cho et al., (2001) and in close conformity to those findings of Gosavi and Bhagat (2009), Mathukia et al., (2014) and Singh et al., (2015) (Table 2).

Fertility had improved yield attributes i.e, baby cob length, baby corn length, baby corn girth, baby corn weight (g) plant ${ }^{-1}$, baby cob weight $(\mathrm{g})$ plant $^{-1}$, total cob and baby corn yield $\mathrm{q} \mathrm{ha}^{-1}$ and green fodder yield with successive increase in fertility level up to maximum level of fertility $F_{3}$ (180-90-90). That might be due to better supply of nutrients which led to the better plant height, more number of green leaves, high value of LAI, increment in SPAD values and significant dry matter accumulation. All such improvement in growth parameter reflected profound growth and development and finely resulted significant increase in yield attributes of baby corn. Saha and Mondal (2006), Panwar and Munda (2006), Singh and Choudhary (2008), Sahoo and Mahapatra (2007) and Panwar (2008) further advocated similar effect of fertility as it has been observed in the present study.
Zinc had improved yield attributes i.e., baby cob length, baby corn length, baby corn girth, baby corn weight $(\mathrm{g})$ plant $^{-1}$, baby cob weight (g) plant $^{-1}$, and green fodder yield with successive increase in zinc level up to maximum level of fertility $\mathrm{Zn}_{2}\left(5.0 \mathrm{~kg} \mathrm{ha}^{-1}\right)$. However, total cob and baby corn yield $\mathrm{q} \mathrm{ha}^{-1}$ could not vary significantly due to zinc level. Higher zinc level $Z_{2}\left(5 \mathrm{~kg}_{\text {zinc ha }}{ }^{-1}\right)$ also had significant effect on number of baby corn plant $^{-1}$, baby corn weight, cob as well as corn girth and green fodder yield.

The increase in yield attributes due to application of zinc was caused by higher chlorophyll contents, and this had apparently a positive effect on photosynthetic activity, synthesis of metabolites and growthregulating substances, oxidation and metabolic activities and ultimately better growth and development of crop, which led to increase in yield attributes of baby corn.

The results were in conformity with Meena $e t$ al., (2013), Kumar and Bohra (2014) and Shivay and Prasad (2014). Zinc fertilization has beneficial effect on physiological process, plant metabolism and plant growth, which leads to higher yield. Increase in cob and corn yield with application of zinc was also reported by Kumar and Bohra (2014).

\section{Effect of plant geometry, fertility and zinc on economics of baby corn}

Perusal of Table 3 reveals that highest net returns (Rs 225774 ha- $^{-1}$ ) and B: C ratio 5.12 had found in $\mathrm{P}_{3}$ (paired row) plant geometry.

The planting geometry of $\mathrm{P}_{3}$ paired row was attributed due to higher yield attributes i.e, baby cob length, baby corn length, baby corn girth, baby corn weight $(\mathrm{g})$ plant $^{-1}$, baby cob weight $(\mathrm{g})$ plant $^{-1}$, total cob and baby corn yield $\mathrm{q} \mathrm{ha}^{-1}$. The results collaborate with the findings of Kumar (2008). 
Increase in fertility level upto $\mathrm{F}_{3}$ (180-90-90) significantly fetched higher net returns (Rs 219108 ha- $^{-1}$ ) and B: C ratio 4.81 in baby corn. This was attributed due to higher yield attributes i.e., baby cob length, baby corn length, baby corn girth, baby corn weight (g) plant $^{-1}$, baby cob weight $(\mathrm{g})$ plant $^{-1}$, total cob and baby corn yield $\mathrm{q} \mathrm{ha}^{-1}$ and green fodder yield. Similar finding was repoted by Jeet et al., (2014) reported highest net return and $\mathrm{B}$ : $\mathrm{C}$ ratio was recorded under $150 \mathrm{~kg} \mathrm{~N}^{-1}$ in QPM hybrids. In the same way, Kumar et al., (2014) reported that yield of cob, corn and green fodder besides gross return, net return and benefit cost ratio increased significantly with application of $125 \%$ RDF (recommended dose of fertilizer) over $100 \%$ RDF.

Zinc level had improved gross return and net return with successive increase in zinc level up to maximum level of fertility $\mathrm{Zn}_{2}(5.0 \mathrm{~kg}$ $\mathrm{ha}^{-1}$ ). Higher gross return (Rs 256212) and net return (Rs 219108) was recorded with $\mathrm{Zn}_{2}$ $\left(5.0 \mathrm{~kg} \mathrm{ha}^{-1}\right)$ application, this might be due to higher yield attributes and green fodder yield of baby corn.

\section{References}

Asif M, Saleem MF, Anjum SA, Wahid MA, Bilal MF. 2013. Effect of nitrogen and zinc on growth and yield of maize ( $\mathrm{Zea}$ mays L.). Journal of Agricultural Research 51(4): 455-464.

Dadarwal, R. S., Jain, N. K. and Singh, D. 2009. Integrated nutrient management in baby corn (Zea mays). Indian $J$. Agril. Sci. 79(12): 1023-1025.

Kumar Balwinder, Ram H, Dhaliwal SS, Singh ST. 2013. Productivity and quality of fodder corn (Zea mays L.) under soil and foliar zinc application XVII International Plant Nutrition Colloquium and Boron Satellite Meeting Proceeding Book 752-753.

Kumar R, Bohra JS. 2014. Effect of NPKS and $\mathrm{Zn}$ application on growth, yield, economics and quality of baby corn. Archives of Agronomy and Soil science 60(9):1193-1206.

Kumar Rakesh, Bohra JS. 2014. Effect of NPKS and Zn application on growth, yield, economics and quality of baby corn. Archives of Agronomy and Soil science 60(9):1193-1206.

Kumar, S., Kumar, A., Singh, J. and Kumar, P. 2016. Growth indices and nutrient uptake of fodder maize (Zea mays L.) as influenced by integrated nutrient management. Forage Res. 42(2): 119123.

Kunjir, S. S., Chavan, S. A., Bhagat, S. B. and Zende, N. B. 2007. Effect of planting geometry, nitrogen levels and micronutrients on the growth and yield of sweet corn. Crop Prot. Prod. 2: 2527.

Mahdi SS, Husain B, Singh L. 2012. Influence of seed rate, nitrogen and zinc on fodder maize (Zea mays) in temperate conditions of western Himalayas. Indian

Mathukia RK, Choudhary RP, Shivranand A, Bhosale N (2014) Response of Rabi sweet corn (Zea mays L. var. saccharata Sturt) to plant geometry and fertilizer. Current Advances Agricultural Science 6(2): 196-198.

Meena SK, Mundra SL, Singh P. 2013. Response of maize (Zea mays) to nitrogen and zinc fertilization. Indian Journal of Agronomy 58(1): 127-128.

Panse, V. G. and Sukhatma, P. V. 1985. Statistical methods for Agricultural workers. ICAR Publication, New Delhi, pp. 336-340.

Ramachandrappa, B. K., Nanjappa, H. V. and Shivakumar, H. K. 2004. Yield and quality of baby corn (Zea mays L.) as influenced by spacing and fertilizer levels. Acta- Agronomica-Hungarica 52(3): 237-243. 
Saha M, Mondal SS. 2006. Influence of integrated plant nutrient supply on growth, productivity and quality of baby corn (Zea mays) in Indo-Gangetic Plains. Indian Journal of Agronomy 51: 202-205

Sahoo SC. 2011. Yield and economics of baby corn (Zea mays L.) as affected by varieties and levels of nitrogen. Range Management Society of India 32: 135137.

Shivay YS, Prasad R. 2014. Effect of source and methods of zinc application on corn productivity, nitrogen and zinc concentrations and uptake by high quality protein corn (Zea mays). Egyptian Journal of Biology 16:72-78.

Singh G, Kumar S, Singh R, Singh SS. 2015. Growth and yield of Baby Corn (Zea mays L.) as influenced by varieties, spacings and dates of sowing. Indian Journal of Agricultural Research 49(4): 353- 357.

Singh D, Choudhary J. 2008. Effect of plant population and fertilizer levels on yield and economics of popcorn (Zea mays var. indurata). Indian Journal of Agricultural Science 78: 370-374.
Thavaprakaash N, Velayudham K. 2008. Light interception and productivity of baby corn as influenced by crop geometry intercropping system and INM practices. Asian Journal of Science Research 1: 72-78.

Thavaprakaash N, Velayudham K, Muthukumar VB. 2005. Effect of crop geometry, intercropping system and integrated nutrient management practices on productivity of baby corn (Zea mays L.) based intercropping systems. Research Journal of Agriculture and Biological Sciences 1: 295-302.

Thavaprakaash N, Velayudham K, Muthukumar VB. 2008. Response of crop geometry, intercropping systems and INM practices on yield and fodder quality of baby corn. Asian Journal of Pharmaceutical Sciences 1(2): 146-152.

Wasnik, V.K., Reddy, A.P.K. and Kasbe, Sudhansu, S. 2012. Performance of winter maize under different rates of nitrogen and plant population in Southern Telangana region. Crop Res. 44(3): 269-273.

\section{How to cite this article:}

Alka Jyoti Sharma, M. K. Singh, Sanjay Kumar and Shweta Shambhavi. 2019. Effect of Plant Geometry, Fertility Level and Zinc Level on Kharif Baby Corn (Zea mays L.). Int.J.Curr.Microbiol.App.Sci. 8(07): 1658-1667. doi: https://doi.org/10.20546/ijcmas.2019.807.197 